\title{
Benjamin Franklin in Scotland
}

\author{
The Hon. Lord Mackenzie-Stuart*
}

In the United States they are still celebrating the bi-centenary of their Constitution. For those who might be tempted to say that the great Philadelphia Convention took place during the summer of 1787 and that today I am behind the times, may I rejoin that the vital first ten amendments - the Bill of Rights, which for many is at the heart of the American Constitution, were not finally agreed until 1792. The United States are therefore perfectly correct in spreading their commemoration over a period of five years. It is, I suggest, only proper that a Scotsman should take note since Scotsmen and Scottish thought played a part in these momentous events.

I do not, however, in the course of a short paper intend to get myself embroiled in an attempt to define the Scottish Enlightenment nor to assess its impact upon the thinking of the Founding Fathers of the American Constitution. Where and how one places the limits of the Scottish Enlightenment seems to me to be a matter of personal choice. No two historians of the period - the literature is vast and I make no claim to have mastered it - seem to adopt quite the same approach.

What does appear important to me, however we define the phenomenon we call the Scottish Enlightenment, is to see the Scotland of the period as a whole. For me, the Scottish Enlightenment embraces not only the contribution made to philosophy and economics but also to jurisprudence (in its true meaning of legal philosophy) and also to science in general, natural philosophy, to use the jargon of the day, to medicine, to architecture and to general literature. The social sciences were not then known by that name but important contributions were being made to their understanding during the period in question. Here the name of Adam Ferguson springs to mind and embodies the spirit of the age. Not only was he a philosopher, a historian and a man of science. He had fought with the Black Watch at the battle of Fontenoy.

The small group of men who assembled at Philadelphia during the summer of 1787 numbered no more than 50 at the most. The intellectual level was astonishingly high, particularly when one remembers that the thirteen colonies

* Sometime President of the Court of Justice, European Communities at Luxembourg. This paper is based on an address given at the Annual General Meeting of the Stair Society, November 1989. 
had only three million inhabitants, but the educational background of the delegates was immensely varied and it is difficult to generalise about the considerations which influenced the Assembly taken as a whole. After the heady days of the Declaration of Independence and the debilitating war that followed, when freedom from foreign domination was the driving force, means had to be found to create a government capable of regulating in the national interest thirteen very different political entities and the means to preserve those entities while creating a coherent whole. All this must be seen, moreover, against the background not of known territory and fixed frontiers, as in sea-grit and landlocked Europe, but with an ill-defined and ever expanding boundary in view. Philosophy has its place, but I believe John Dickinson of Delaware to have been right when on Monday, 13th August, 1787, he said at Philadelphia: "Experience must be our only guide. Reason may mislead us." 1

With that introduction the moment has come to present our principal player. Every century produces a handful of men whose influence is felt beyond the boundaries of their land. Of these a few, a very select few, cross the barriers of time in the sense that their discoveries have changed the world in which we live. Among such I class Benjamin Franklin.

He was born in Boston in 1706, the fifteenth child of seventeen, the son of a poor candle-maker. He apprenticed himself to his elder brother James, a printer. James was something of a rebel against the prevailing theocratic approach of the New England regime and he encouraged Benjamin to supplement his almost total absence of formal education. We are told that Benjamin owed much to Locke's Essay on Understanding and to Addison's Spectator. He did not stay long, however, with his brother James but made the first of his four transatlantic crossings to complete his apprenticeship with printers in London where he stayed, close to penury, for some three years.

The years following his return need not detain us except to say that during that period we see him becoming a man of consequence in his adopted Pennsylvania; printer, publisher - including that of a newspaper in German for the Pennsylvania 'Dutch', i.e., 'Deutsch' - president of an Insurance Company and occupied with a multitude of public activities. By 1746 he was a member of the Philadelphia Municipal Council and in $\mathbf{1 7 5 0}$ he became a member of the Pennsylvania Assembly. During the French and Indian wars he was to be seen in the uniform of colonel in the British army and he played a notable part in the campaign of 1755 though whether he actually received a commission signed by His Majesty King George II remains in doubt.

In the 1750's dissatisfaction was beginning to be felt by the American colonists as regards their treatment by London. Again space does not permit of detailed description but it is essential to remember that in the two decades leading up to the Declaration of Independence the problems besetting the colonies, while they may 
have had much in common, were by no means the same. Pennsylvania, in particular, was a constitutional curiosity.

Until 1776, it was the personal property of the Penn family, under the Crown to be sure, but none the less no different from a large country estate. It had its Assembly but in the last resort it was, in Franklin's day, the Penn brothers who were resident in London who had the last word. When in 1757 Benjamin Franklin was appointed the Pennsylvania Agent in London he had to contend not only with an unsympathetic Government but with his own proprietors who had attempted to block his appointment in the first place.

Franklin's second stay in London, although intended to be relatively brief, lasted until August 1762. Moreover only two more years were to elapse before the American packet once again, in December 1764, disembarked Franklin on the quays of Portsmouth this time for a sojourn of 11 years. He returned to the United States in time enough, however, to be one of the signatories of the Declaration of Independence. Yet again he was prevailed upon to cross the Atlantic to represent the independent colonies at the Court of France - there is a superb drawing by Gabriel de St Aubin of Franklin presenting his credentials to Louis XVI. There he remained until he returned to the United States to take part - given his age a minor part - in the great Constitutional debate of 1787 . He died only three years later but I like the picture of the most talented American of his age nodding in the stuffy atmosphere of Independence Hall, Philadelphia, during the hot summer, legitimating by his presence the whole proceedings.

All that would be enough for most of us to assure our niche in the Halls of Fame. But it was not Franklin the patriot, Franklin the diplomat, Franklin the philosopher that attracted the most acclaim in his lifetime. It was Franklin the scientist. In February of 1759, the University of St Andrews conferred upon Franklin the degree of Doctor of Laws and the University Minute designs him solely as "famous for his writings on Electricity".

For the rest of his life Franklin was commonly referred to - presumably with his approval - as 'Doctor', even after Independence. It is not every citizen of the United States who is aware that the doctorate was a Scottish one.

St Andrews singled out Franklin's contribution to our knowledge of electricity and this was probably his most important single discovery. Everybody knows that he was the first to discover the true, or by modern standards approximately true, nature of electricity. All of us have some picture of Franklin's proof of his theories by flying a kite in a thunderstorm, the kite having attached to it a silk thread capable of being charged with electricity. The crux of the experiment, of course, was when Franklin approached a metal key hung from the silk thread and generated a spark. Not so many are aware that the next two persons who attempted the same hazardous experiment died in the process. To those of a speculative turn of mind may I add the following thought? I quote from Azimov's Biographical Encyclopaedia of Science and Technology: ${ }^{2}$

2. Pan Books (London, 1975), para. 531. 
"When a quarter of a century later the aged Franklin represented the infant United States during the Revolutionary War at the Court of France he proved the ideal man for the job. Not only did his carefully affected Republican simplicity perversely appeal to the aristocrats of Versailles, but it was the Age of Reason, and educated Frenchmen fell all over the man who had tamed the lightning of the sky and brought it to earth. How much of America's successful birth can be traced back to a kite flying in a thunderstorm?"

All this is only to tell half the story. The nature of the Gulf Stream, bi-focal spectacles, lead poisoning, the lightning conductor as it is in daily use today, the art of learning to swim and canal transportation all find their place in his voluminous correspondence and publications by which he sought to exhort and to encourage. For our purposes today I single out his efforts to devise a fuel-efficient and smokeless fireplace. Of this more anon, but at this stage may I recall that one of the earliest prospectuses of the Carron Company advertised ranges "Made on the model of Dr Franklin's Philadelphia stove."

Which, appropriately, brings us back to Scotland. Franklin made two visits to Scotland. The first lasted from the beginning of September 1759 until the middle of October. ${ }^{3}$

Why a voyage to Scotland? Well, why not? Franklin was an enthusiastic traveller. He had many Scottish friends in Philadelphia and in London. William Strahan, his Edinburgh born but London based agent and friend of twenty years standing, did business in both capitals and above all the growing importance of Scotland in the sciences as well as the arts must have attracted him. Moreover it is reasonable to suppose that he wished, as in fact he did, to receive in person his doctorate from St Andrews University.

Franklin, accompanied by his son William, left London at the end of the first week in August and proceeded in a fairly leisurely fashion by the West Coast route. On August 29, we find him writing to his wife from Liverpool "we have been out now almost three weeks" and even then it was not entirely certain whether affairs of state would allow him to continue the journey as planned. A word about William Franklin. He was almost certainly illegitimate - "spawned by an oyster wife" as one rather disagreeable divine was to say later. William, however, was at that time a personable young man, a member of the Middle Temple but actively lobbying for a government post. In this he was eventually successful, being made Governor of New Jersey. It was, I suppose, inevitable that father and son should fall out over the issue of independence and William died an embittered old man in English exile.

The party finally arrived in Edinburgh on September lst or 2nd. I am not going to attempt a day-by-day reconstruction of their activities. We know that the Franklins found lodgings with Mrs Cowan in Milne Square, then a most

3. I do not give detailed references for what follows. I obviously owe much to J. Bennett Nolan, Benjamin Franklin in Scorland and Ireland (Philadelphia, 1938). Since then there has been the magnificently edited Yale edition of the Papers of Benjamin Franklin. 
respectable address, so we know that Benjamin was exposed to the horrors of life in the old town, horrors which need no describing to an Edinburgh audience. In 1759 the Nor'Loch was as yet undrained and work on the New Town had not yet commenced.

On 5 September the Franklins, father and son, were admitted Guild Brethren of the City of Edinburgh at a ceremony presided over by the great Lord Provost Drummond who has every claim to be considered the father of the New Town. As is obvious, such a ceremony could not have been arranged at very short notice so Franklin's arrival must have been expected. While the minutes of this occasion are extant the contemporary press reports are meagre, popular attention being more diverted by the presence in Craig's Close of a camel and a dromedary which daily attracted fascinated throngs.

To cut matters short, however, during his stay in Edinburgh Franklin met to our recorded knowledge almost all the circle of friends and acquaintances whom we associate with the Scottish Enlightenment. Above all Lord Kames and Sir Alexander Dick, but also both the professors Munro, Adam Ferguson, Joseph Black and Doctors Cullen and Russell, the future Principal Robertson and Adam Smith - in all, you would agree, an impressive galere.

There is a well known passage in the memoirs of the Reverend Alexander Carlyle - 'Jupiter' Carlyle - describing a dinner given by Dr Robertson at which among other guests of distinction was David Hume and this is usually cited as being the first of many meetings between the two men. Other sources, however, suggest that David Hume was not in Edinburgh during Franklin's first visit. Carlyle does not seem to have taken much to Benjamin Franklin but in this he is exceptional and the reason may be that he had too many friends in the Penn faction.

On 17 September, Franklin left Edinburgh for Glasgow, passing en route the site of the new Carron Ironworks. In 1759, Glasgow was a quiet country town but already with a reputation for the quality of the ships which were built on the banks of the Clyde. Despite its Calvinist reputation for low living and high thinking General Wolfe, whose death on the Plains of Abraham took place almost to the hour when Franklin was visiting Sir Alexander Dick at Prestonfield, described his service there as "dismal quarters with suppers of the most execrable food on earth and wines that approached a poison" - Glasgow was a thriving centre for trade in Virginia tobacco and Jamaica rum.

Apart from other contacts Franklin was particularly interested in the workshop of Alexander Wilson who had his type-foundry on University premises. Franklin had been commissioned by his Philadelphia partner, David Hall, to buy a set of Wilson type for the Philadelphia Gazette although in the end he did not do so, preferring the better known Caslon in London. Also in the same university quandrangle were the premises of the Foulis brothers, certainly Scotland's most distinguished printers of the eighteenth century. We know that Franklin visited the Foulis brothers as befitted one printer to another. There is, unfortunately, no 
record of his having visited the next shop but one where he would have found a sickly young mechanic, largely occupied in repairing musical instruments, whose inventions were to transform the first half of the nineteenth century as Franklin's were the second - one James Watt.

The next week or two were taken up with a Highland visit, perhaps including a visit to Inverary, and on 2 October Franklin was in St Andrews where he was admitted a Guild Brother and received by the University in their Library, presumably the self-same library described by Boswell a few years later when he was unable to show it to Dr Johnson because some-one had lost the key. Despite certain fanciful reconstructions there is no evidence of any public ceremony - the degree had after all been conferred some months previously - nor any warrant for the attendance of a certain undergraduate of the day, one James Wilson, later to be a signer of both the Declaration of Independence and the Constitution and first associate Justice of the new Supreme Court of the United States. A pity, because such a meeting is not impossible since St Andrews had only forty undergraduates at that time and such a meeting would at least have been ben trovato.

From 4 October to the end of the visit on 12 October the Franklins were occupied again by the social round. During this week they found time, in the company of Sir Alexander Dick and Lord Provost Drummond, to visit the Royal Infirmary, as some years later Franklin was to write to Sir Alexander Dick saying of its Philadelphia equivalent "we have imitated the Edinburgh Institution of the Infirmary in that remote Part of the world." It was from this period too that Franklin's friendship with Lord Kames can effectively be dated, although they had earlier been in correspondence (and on the return journey to England the Franklins stayed with Lord and Lady Kames at Kames in Berwickshire). This week also included some days at Prestonfield where Sir Alexander Dick dispensed his habitual hospitality - he once said to Boswell that he averaged a thousand guests a year.

At least as important as the visit itself was the correspondence which ensued between Franklin and the friends he had made or whose friendship had deepened on re-acquaintance.

In many ways it is Franklin the scientist, Franklin the practical engineer who comes to the fore.

As an example, take the famous Franklin fire-place which he refused to patent, saying, with remarkable liberality that "As we enjoy great advantages from the inventions of others, we should be glad of an opportunity to serve others by any invention of ours, and this we should do freely and generously." Most would agree that this sentiment is seldom expressed today. Sir Alexander Dick was the recipient of a Franklin stove and one was recommended to Lord Kames for the house which he had inherited through his wife at Blair Drummond.

An allied problem, much in evidence in the correspondence, was that of the smoking chimney, a problem with which Lord Kames was sorely afflicted. Of this Franklin had to say (and I take this quotation at random): 
"I have, as you have heard, been dealing in Smoke: and I think it not difficult to manage, when one is once acquainted thoroughly with the principles. But as the causes are various so must be the Remedies; and one cannot prescribe to a Patient at such a Distance without first having a Clear State of its Case ..."

Before I come to Benjamin Franklin's second visit to Edinburgh, which I shall deal with quite briefly, let me give some explanation of the two most important points which I am trying to make lest it be asked what all this has to do with the development of Scots law.

The first I have already mentioned in passing. For any scholar of the eighteenth century, as was the case in earlier centuries, knowledge was a single unseamed garment. Moral philosophy on the one hand, natural philosophy on the other, were equally the proper subjects of study of any man who claimed himself to be educated. This was as true of the lawyer as anyone else. Take Lord Kames, although perhaps he was an extreme example. We are indebted to Professor David Walker for the best modern account of Lord Kames, in which he quotes Boswell as saying: "Lord Kames is a man of uncommon genius, great application and extensive knowledge ..."4 Today it is his knowledge of matters outside the field of law and legal philogophy which I would like to emphasise. Kames was also, "a Commissioner for the Forfeited Estates . . . amongst other acts prompting Walker's and Wight's tours and surveys of large tracts of Scotland, a Trustee of the Board of Trustees for Fisheries, Manufactures and Improvements in Scotland from 1755 to 1782, which largely transformed the country from a backward one to an advanced one, as promotor of improved transport facilities, notably the Forth and Clyde Canal and a protagonist in the 1750's and 1760's of the schemes to erect the North Bridge, drain the Nor'Loch, and begin the development of the New Town of Edinburgh."'5

In return we find Franklin sending to Philadelphia both Kames's Law Tracts and his Principles of Equity. Moreover, Franklin whiled away time on his return voyage in 1762 reading Kames' Elements of Criticism.

So Franklin's visit to Scotland and the warmth of his reception there provide a clear and concrete illustration of the universality of knowledge to which every educated man aspired in the eighteenth century - a factor which no historian, and that includes the legal historian, can ignore.

If $I$ have been at pains to emphasise the welcome given to Franklin the scientist there is another reason why Franklin's Scottish connections are of interest to the legal historian. This time it is Franklin the diplomat and politician with whom we are concerned. The editors of the Franklin papers have, inevitably, found many gaps among the extant Franklin - Kames exchange of correspondence. One such gap concerns Lord Kames' view on the mounting tension between the London Government and the American colonies. That Lord Kames had an opinion on the matter goes without saying.

4. The Scottish furists, p. 240.

5. Walker, ibid., p. 238. 
There is, however, the text of a long letter written by Franklin to Lord Kames in the early part of 1767 and which could easily become the subject of a paper in its own right. By some mischance the letter never reached Lord Kames in 1767 and he had to be supplied with a copy in February 1769. This we know from a postscript to a letter of 21 February from Franklin to Kames in which characteristically the chief topic is not politics but the advantage of using oxen rather than horses to pull the plough and cart. Horses, said Franklin, require twice the quantity of land to maintain them, and "after all are not good to eat, at least we don't think them so." The postscript in question ends prophetically - we are still seven years away from the Declaration of Independence - "Things daily wear a worse aspect, and tend more and more to a Breach and final Separation."

The 1767 letter (which exists in two versions) ${ }^{6}$ contains a clear and well-ordered presentation of the situation seen through the eyes of the colonists. It is the more interesting since we perhaps forget that until the eve of the Declaration of Independence Franklin thought of himself as a Briton - he frequently describes himself as such and even had thoughts of settling permanently in the United Kingdom.

"It becomes a matter of great importance that clear ideas should be formed on solid Principles both in Britain and America, of the true political relation between them, and the mutual duties belonging to that Relation. Till this is done, they will be often jarring. I know none whose Knowledge, Sagacity and Impartiality, qualify them so thoroughly for such a Service, as your do you."

Alas, I can find no trace of Kames having ever responded to Franklin's entreaty nor, indeed, of any Scottish reaction to what with hindsight has turned out to be the most important single event of the eighteenth century, the independence of the American colonies.

Desirous as he was to maintain the union between Britain and the colonies Franklin was characteristically realistic. He continues:

"As to America, the advantages of such a Union to her are not so apparent. She may suffer at present under the arbitrary Power of the Country; she may suffer for a while in a Separation from it; but these are temporary evils that she will outgrow. Scotland and Ireland are differently circumstanc'd. Confined by the Sea, they can scarcely increase in Numbers, Wealth and Strength so as to overbalance England. But America, an immense Territory, favoured by Nature with all advantages of climate, soil, great navigable Rivers and Lakes etc., must become a great country, populous and mighty; and will in a less time than is generally conceived be able to shake off any Shackles that may be imposed on her, and perhaps place them on the Imposers. In the mean time, every Act of Oppression will sour their tempers, lessen greatly if not annihilate the profits of your commerce with them, and hasten their final Revolt: For the seeds of Liberty are universally sown there, and nothing can eradicate them."

6. See the Yale edition of Franklin's papers, Vol. 14, p. 62, for a discussion of the problem. 
This astonishingly moderate and far-seeing assessment has to be understood against the legal and political events of the $1760 \mathrm{~s}$. The circumstances leading up to the Declaration of Independence in 1776 are commonly presented as a series of blunders by the British Government. Blunders there certainly were but the premise from which the Government started was entirely rational. The colonies required protection. Their trade routes had to be kept open; there were constant threats from the French and from the Indian tribes. The colonists were unable or, at least, unwilling to discharge this responsibility themselves. The only alternative was a substantial British military presence and this had to be paid for. By the end of the War of the Austrian Succession the British Treasury was empty. It was only reasonable that costs incurred for the benefit of the colonies should be supported by the colonists themselves and the justice of this proposition was recognised by most of them.

It was the heavy-handed and uncomprehending manner of its execution which gave rise to resentment and which provoked the great constitutional debate.

To summarise that debate in a couple of paragraphs is impossible but it puts Franklin's letter to Lord Kames in perspective to recall that in the immediately preceding years there had been three crucial items of legislation affecting the daily lives of the colonists, the Proclamation of 1763, the Sugar Act of 1764 and the Stamp Act of 1765. The first prevented further settlement beyond the Alleghenies at a moment when western expansion was taking place. The object of the Proclamation was to maintain good relations with the Indian tribes which were the source of the valuable fur trade. The Sugar Act levied a duty on the import of molasses. There was nothing new in this. Such a duty already existed as a trade measure. The innovation lay in the express statement in the Act that its purpose was to defray the expenses of protecting the colonies - that is to say, it was a revenue act. So, too, was the Stamp Act which imposed a stamp duty on a wide range of documents and affected individuals and business alike.

It was this legislation which initiated the constitutional polemic which was to continue until the knot was finally severed by separation. What were the respective powers of the Crown, the British Parliament and the colonial assemblies and legislatures? Was the final arbiter to be found in the principles of natural law to which even the British Parliament was subject or was the true basis to be sought in some form of social contract? Was there a distinction to be made between taxation which affected the colonies internally and taxation which affected only their external trading relations? Franklin in his famous examination at the bar of the House of Commons in 1766 had, erroneously as most now accept, agreed that the distinction was valid.

The repercussions of this debate must have been felt in Scotland. As has been said, the contribution of the Scottish Enlightenment to the making of the American Constitution has been studied. What is missing is any study of the Scottish reaction to the colonial protests. Is this not a field for further investigation by the constitutional lawyer and historian? English material exists in plenty as, for 
example, in the debate before both Houses of Parliament concerning the repeal of the Stamp Act, which was equally unpopular with British merchants, and in the subsequent writings of Edmund Burke, but the Scottish attitude, so far as I know, remains uncharted ground.

Franklin's second Scottish visit must be dealt with more briefly. Although we have the diary of Henry Marchant of Rhode Island which covers a visit by Franklin to Glasgow and, on the return, to the Carron Company, Marchant's narrative lacks sparkle and the surviving correspondence is meagre.

However on 27 October 1771 we find Franklin writing to his old friend William Strahan in London:

"Thro' Storms and Floods I arrived here on Saturday night, late, and was lodged miserably at an Inn; but that excellent Christian David Hume, agreeable to the precepts of the Gospel, has received the Stranger and I now live with him at his House in the New Town most happily."

The reference to the "new town" is interesting since Edinburgh had greatly changed in the twelve years between the two visits. Much of Milne's Court, Franklin's former abode, had been demolished to allow for the construction of the magnificent North Bridge, at last opening Edinburgh to the North. The Nor'Loch had been drained and although conditions in the old town remained as unsalubrious as ever the New Town was taking shape. David Hume's house in St David's Street was among the first to be occupied and Franklin must have been one of his first guests. One of the more endearing aspects of the philosopher was his love of good food - his cook Peggy Irvine had the reputation of being the best in Edinburgh - and at least one dinner party is recorded with Lord Kames, Dr Black, the professor of chemistry, Russell, the professor of physics, and Adam Ferguson among the guests. Doubtless there were many such.

Most of Franklin's friends from his first visit had survived and many were in Edinburgh to welcome him. Robertson was now Principle of the University and duly received Franklin at his house after breakfast on 31 October. Marchant notes in his diary that:

"The conversation was much on America's Affairs. The Geography of ye Country etc etc with somewhat respecting Scotland \& England and her Policy with the Colonies. Dr Robertson from his conversation I take to be a friend to Civil and Religious Liberty and fully imagines America must in some future period be the seat of a Mighty Empire."

Again one would like to know so much more.

To summarise events: On 6 November Marchant and Franklin set out for Blair-Drummond, by then the property of Lord and Lady Kames. There is mention of passing en route the Forth and Clyde Canal then under construction and the Carron works to which they were to pay a full day's visit later. Franklin and Marchant stayed at Blair-Drummond, in part held up by bad weather, until 16 November. The visit seems to have been an extremely happy one but although Marchant is ecstatic about the estate and the "Sumptuous \& Lordly and 
Hospitable" entertainment offered, there is no account of Lord Kames' views on the problems of the American colonies nor, indeed, of any other topic of conversation.

At Glasgow, the travellers again visited the University, Franklin, as might be expected, being particularly occupied with Wilson's type-foundry - "one of the grandest Foundry of Types in Europe", according to Marchant - and with the Foulis Press. Then via the Carron Company, which was already making some of the preliminary castings for James Watt's steam engine as well as cannon for the War of Independence, back to Edinburgh on 17 November. Only a few more days remained. On Tuesday, Dr Franklin dined with Lord Kames and on the Wednesday with Adam Ferguson, leaving Edinburgh on Thursday 21st, taking two full days to reach Carlisle.

One curious omission on this second trip was a visit to Prestonfield House to see his old friend Sir Alexander Dick; there is a letter, dated January 11, 1772, to Dick in which Franklin apologises for this saying: "My last Expedition convinc'd me that I grow too old for Rambling, and that 'twas probable I should never make such another journey."

In fact Franklin's days of travel were far from over. Four more years in London remained, years of increasing disappointment. In 1775 he returned to America to participate in the events leading to the Declaration of Independence. In 1778 he was accredited to the Court of Versailles as the ambassador of the new United States of America and spent the best part of ten years there securing the French help so essential in bringing the War of Independence to a successful end successful that is from the American point of view. It is, however, probable that his second visit to Scotland ended his days of carefree, inquisitive "Rambling".

Earlier in this paper I pictured the elderly Franklin dozing through the sultry summer meeting at Philadelphia when the American Constitution was created. Of that distinguished group of men, two were native born Scots both of whom I have mentioned, James Wilson, educated at St Andrews and Glasgow, and John Witherspoon, late of the Laigh Kirk of Paisley and Principal of Princeton. Wilson was too young to have known well the great names of the Scottish enlightenment and Witherspoon was a man apart - it has even been suggested that he accepted the post at Princeton because of his disenchantment with the more liberal views of moderate churchmen such as Principal Robertson of Edinburgh. One may argue, and the debate continues, about the part played by Scottish thinking in the solution finally adopted at Philadelphia but it was Benjamin Franklin alone - and this is why I commend him to your attention - who had not only read the works of the Scottish enlightenment but was on easy and cordial terms with the authors. Perhaps yet, in some unexplored archive, there is more to be discovered. 